\title{
UNJUK KERJA MESIN DIESEL TERHADAP PENAMBAHAN
} TURBOCHARGER

\section{Rasdy Yunandi, Abrar dan Steven}

Universitas Tarumanagara Jakarta, Indonesia

Email: rasdy.515150042@stu.untar.ac.id, abrarr@ft.untar.ac.id dan stevend@ft.untar.ac.id

\begin{tabular}{l}
\hline INFO ARTIKEL \\
\hline Diterima \\
10 Februari 2021 \\
Direvisi \\
15 Februari 2021 \\
Disetujui \\
15 Maret 2021
\end{tabular}

\section{Keywords:}

turbocharger; diesel

engine; power; torque

\begin{abstract}
The times that are increasingly rapid demand development in all fields, fields of technology, demand for programs and demands theat demand that technology be familiar with the environment, and use or consume fuel as economically as possible and high performance. To achieve this, of course an additional device is needed, one of which is by using a turbocharger. In this experiment we will compare the value of engine performance when using a turbocharger and when not using a turbocharger when using a turbocharger increases engine power. The purporse of this study was to determine the difference in power produced by a diesel engine that uses a turbocharger and a diesel engine that does not use a turbocharger, by collecting secondary data that has been previously tested for analysis, and proceing into a graph to see the differences mada bye the use of a turbocharger
\end{abstract}

\begin{abstract}
ABSTRAK
Perkembangan zaman yang semakin pesat menuntut perkembangan di segala bidang, bidang teknologi, permintaan program dan menuntut permintaan agar teknologi akrab dengan lingkungan, dan menggunakan atau mengkonsumsi bahan bakar sebesar mungkin secara ekonomis dan kinerja tinggi. Untuk mencapai hal tersebut, tentunya diperlukan perangkat tambahan, salah satunya dengan menggunakan turbocharger. Dalam eksperimen ini kita akan membandingkan nilai kinerja mesin saat menggunakan turbocharger dan ketika tidak menggunakan turbocharger saat menggunakan turbocharger yang berfungsi untuk meningkatkan tenaga mesin. Tujuan dari penelitian ini adalah untuk mengetahui perbedaan daya yang dihasilkan mesin diesel yang menggunakan turbocharger dan mesin diesel yang tidak menggunakan turbocharger, dengan mengumpulkan data sekuder yang telah diuji sebelumnya
\end{abstract}




\begin{tabular}{ll}
\hline Kata Kunci: & untuk dianalisis, dan diolah menjadi grafik untuk dapat \\
turbocharger; & mesin \\
diesel; kekuasaan; torsi & $\begin{array}{l}\text { dilihat perbedaan yang dihasilkan oleh penggunaan } \\
\text { turbocharger. }\end{array}$ \\
\hline
\end{tabular}

Coresponden Author

Email: rasdy.515150042@ stu.untar.ac.id

Artikel dengan akses terbuka dibawah lisensi

\section{Pendahuluan}

Perkembangan zaman yang semakin pesat menuntut adanya kemajuan didalam segala bidang terutama didalam bidang teknologi. Salah satu bidang teknologi yang mengalami kemajuan adalah dalam bidang otomotif. Kemajuan didalam bidang ini dapat kita lihat pada kendaraan-kendaraan sekarang yang selalu ingin meningkatkan rasa kenyamaan, kepuasan keamanan dan ramah lingkungan (Hendrawan et al., 2020).

Tuntutan program dan permintaan konsumen yang menuntut agar teknologi haruslah akrab dengan lingkungan, dan pemakaian atau konsumsi bahan bakar yang sehemat mungkin (Mahfudiyanto et al., 2020). Hal ini merupakan tantangan tersendiri untuk para perancang otomotif atau para insinyur untuk terus berupaya dan berinovasi menciptakan kenderaan dengan tingkat polusi yang serendah- rendahnya, hemat bahan bakar serta mempunyai performa yang tinggi (Nasution \& Ibrahim, 2017).

Salah satu cara peningkatan unjuk kerja mesin diesel dapat dilakukan dengan memperbaiki sistem pemasukan dan pengeluaran udara, untuk memperoleh hal tersebut tentu diperlukan suatu perangkat tambahan salah satu diantaranya dengan memakai turbocharger (Ginting \& Hazwi, 2014). Turbocharger adalah sebuah komponen yang berupa kompresor yang digunakan dalam mesin pembakaran dalam untuk meningkatkan performa mesin (Nasution \& Ibrahim, 2017).

Tujuan dari penelitian ini adalah untuk mengetahui seberapa besar perbedaan daya dan torsi yang dihasilkan oleh mesin diesel yang menggunakan turbocharger dan mesin diesel yang tidak menggunakan turbocharger dengan menggumpulkan data sekunder yang sudah ada dan telah diuji sebelumnya untuk dianalisi dan diolah dalam bentuk grafik.

\section{Metode Penelitian}

Metode penelitian yang digunakan pada penelitian ini adalah dengan mengumpulkan beberapa data sekunder, kemudian melalui data yang sudah didapatkan akan diolah dan dianalisis dengan mencari delta daya dan torsi mesin diesel. Data olahan tersebut akan dibuat menjadi grafik untuk dapat dilihat perbedaan dari hasil performa mesin yang dihasilkan dari penggunaan turbocharger (Purwanto, 2005). Pembuatan analisa berdasarkan data dan grafik yang sudah didapat dari data yang telat diuji sebelumnya untuk dijadikan kesimpulan.

Data sekunder yang dikumpulkan 3 jurnal untuk dimasukkan ke laporan jurnal, yang dimana dibagi jadi 2 jenis percobaan dimana percobaan 1 adalah percobaan 
perbandingan performa mesin yang menggunakan turbocharger, dan untuk percobaan 2 adalah percobaan perbandingan performa mesin tanpa menggunakan turbocharger.

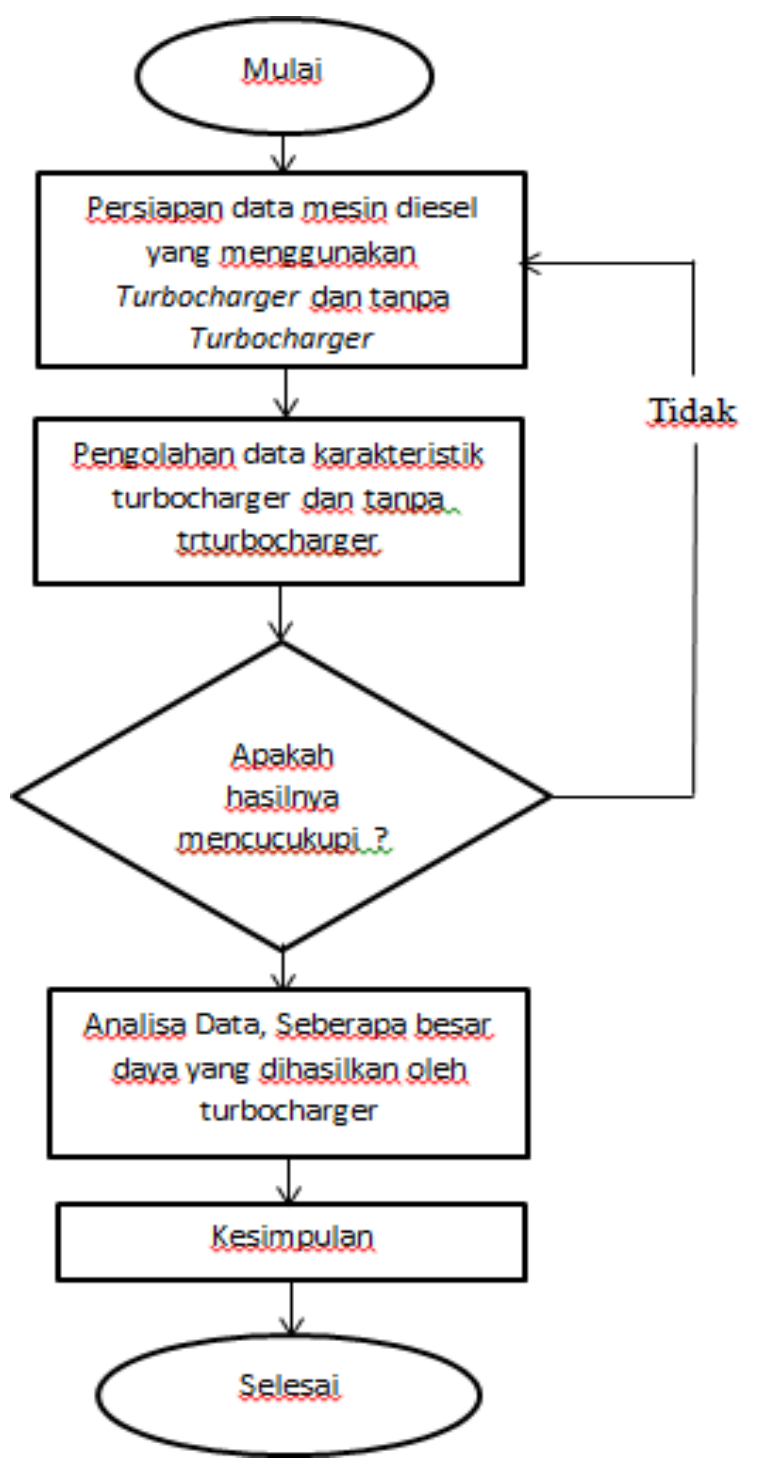

Gambar 1

Flowchart Pengambilan Data

\section{Hasil dan Pembahasan}

1. Percobaan Performa Mesin Untuk Data Mesin Disel dengan Turbocharger

Berikut merupakan data karakteristik turbocharger yang digunakan saat melakukan uji coba dengan menggunakan mesin mobil diesel turbocharger yang diuji dengan dynamometer (Yusuf et al., 2019). 


\section{Tabel 1}

Data Hasil Pengujian Daya dengan Turbocharger dan Tanpa Turbocharger

(Yusuf et al., 2019)

\begin{tabular}{ccc}
\hline Rpm & $\begin{array}{c}\text { Max Power Tanpa } \\
\text { Turbocharger }\end{array}$ & $\begin{array}{c}\text { Max Power Dengan } \\
\text { Turbocharger }\end{array}$ \\
\hline 1000 & 15.47 N.m. & 15.06 N.m. \\
\hline 1200 & 19.81 N.m. & 19.97 N.m. \\
\hline 1400 & 23.37 N.m. & 23.71 N.m. \\
\hline 1600 & 26.8 N.m. & 28.66 N.m. \\
\hline 1800 & 30.55 N.m. & 33.19 N.m. \\
\hline 2000 & 33.72 N.m. & 37.62 N.m. \\
\hline 2200 & 36.92 N.m. & 38.91 N.m. \\
\hline 2300 & 38.4 N.m. & 40.33 N.m. \\
\hline 2400 & 39.71 N.m. & 42.27 N.m. \\
\hline 2600 & 41.56 N.m. & 44.82 N.m. \\
\hline 2800 & 44.57 N.m. & 46.17 N.m. \\
\hline 3000 & 47.18 N.m. & 48.57 N.m. \\
\hline 3200 & 49.13 N.m. & 51.32 N.m. \\
\hline 3400 & 50.87 N.m. & 53 N.m. \\
\hline 3600 & 51.53 N.m. & 54.77 N.m. \\
\hline 3800 & 52.15 N.m. & 57.24 N.m. \\
\hline 3900 & 51.26 N.m. & 55.54 N.m. \\
\hline 4000 & 50.67 N.m. & 54.56 N.m. \\
\hline
\end{tabular}

Pada table 1 dapat dilihat perbandingan daya mesin dengan turbocharger dan tanpa turbocharger pada rpm berbeda. Untuk daya maksimum tertinggi diperoleh pada $3800 \mathrm{rpm}$ di mana mesin dengan menggunakan turbocharger memiliki daya maksimum sebesar 57,24 N.m, sedangkan mesin tanpa turbocharger memiliki daya maksimum sebesar 52,15 N.m (Sumardiyanto \& Susilowati, 2017). Pada putaran $3800 \mathrm{rpm}$, diperoleh daya maksimum untuk mesin dengan turbocharger sebesar 54,56 N.m dan mesin tanpa turbocharger sebesar 50,67 N.m. Jika dilihat perbandingan dari putaran mesin yang berbeda dapat dikatakan bahwa mesin dengan menggunakan turbocharger memiliki keunggulan dari sisi keluaran daya maksimum dibandingkan dengan mesin tanpa turbocharger (Yusuf et al., 2019). 


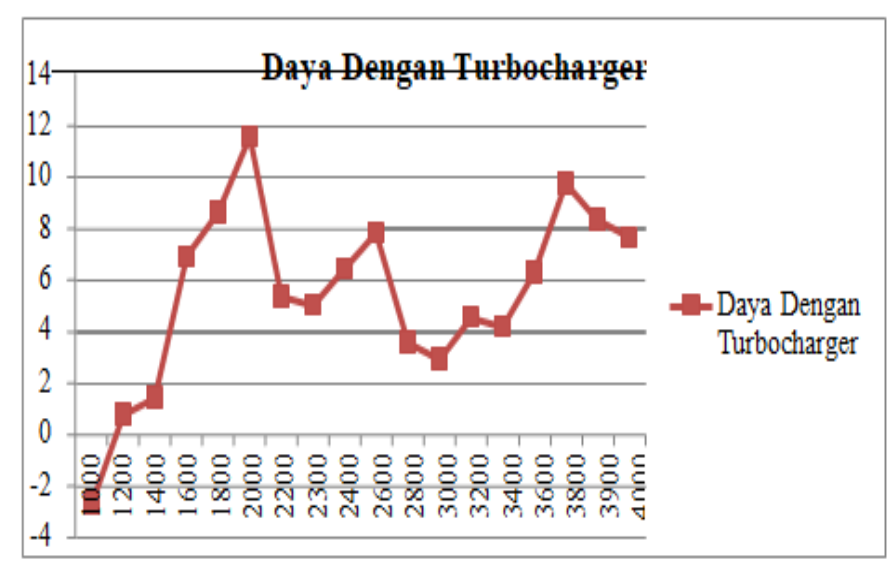

\section{Grafik 1}

Delta Daya dari Percobaan 1

Pada grafik 1 dapat disimpulkan bahwa delta daya maksimal yang dihasilkan mesin dengan menggunakan turbocharger mengalami peningkatan daya sebesar 11,57\% dari putaran $1000 \mathrm{rpm}$ sampai $2000 \mathrm{rpm}$, sedangkan pada putaran $3000 \mathrm{rpm}$ mesin mengalami penurunan daya sebesar $2,95 \%$ dan daya mesin kemabali naik pada putaran $3800 \mathrm{rpm}$ dengan daya sebesar $9.76 \%$.

\section{Tabel 2}

Data Hasil Pengujian Torsi dengan Turbocharger dan Tanpa Turbocharger (Yusuf et al., 2019)

\begin{tabular}{ccc}
\hline Rpm & $\begin{array}{c}\text { Max Torque kg.m } \\
\text { Tanpa Turbocharger }\end{array}$ & $\begin{array}{c}\text { Max Torque kg.m } \\
\text { Dengan Turbocharger }\end{array}$ \\
\hline 1000 & 15.06 N.m. & 14.67 N.m. \\
\hline 1200 & 16.07 N.m. & 16.2 N.m. \\
\hline 1400 & 16.25 N.m. & 16.49 N.m. \\
\hline 1600 & 16.31 N.m. & 17.44 N.m. \\
\hline 1800 & 16.52 N.m. & 17.95 N.m. \\
\hline 2000 & 16.41 N.m. & 18.31 N.m. \\
\hline 2200 & 16.34 N.m. & 17.22 N.m. \\
\hline 2300 & 16.25 N.m. & 17.07 N.m. \\
\hline 2400 & 16.11 N.m. & 17.15 N.m. \\
\hline 2600 & 15.56 N.m. & 16.78 N.m. \\
\hline 2800 & 15.5 N.m. & 16.05 N.m. \\
\hline 3000 & 15.31 N.m. & 15.76 N.m. \\
\hline 3200 & 14.95 N.m. & 15.61 N.m. \\
\hline 3400 & 14.57 N.m. & 15.18 N.m. \\
\hline 3600 & 13.93 N.m. & 14.81 N.m. \\
\hline 2800 & 13.36 N.m. & 14.67 N.m. \\
\hline 3900 & 12.8 N.m. & 14.86 N.m. \\
\hline 4000 & 12.35 N.m. & 13.28 N.m. \\
\hline
\end{tabular}

Pada table 1 dapat dilihat perbandingan torsi mesin dengan turbocharger dan tanpa turbocharger pada rpm berbeda. Untuk daya maksimum tertinggi diperoleh 
pada $2000 \mathrm{rpm}$ dimana mesin dengan menggunakan turbocharger memiliki daya maksimum sebesar 18,31 N.m, sedagkan mesin tanpa turbocharger memiliki daya maksimum sebesar 16,41 N.m. Pada putaran maksimum untuk mesin dengan menggunakan turbocharger sebesar 13,28 N.m di posisi $4000 \mathrm{rpm}$ lebih tinggi jika dibandingkan dengan mesin tanpa turbocharger yang memperoleh torsi sebesar 12,35 N.m (Yusuf et al., 2019).

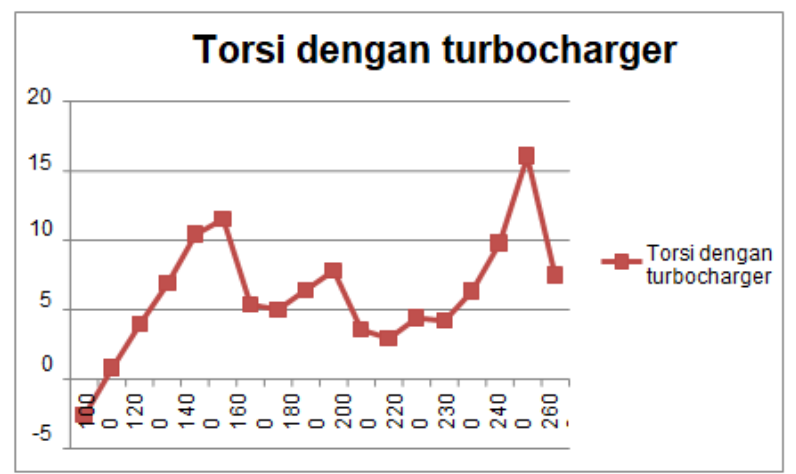

Grafik 2

Delta Torsi dari Percobaan 1

Pada grafik 2 diperlihatkan delta torsi mesin diesel dengan menggunakan turbocharger mengalami peningkatan sebesar 11,58 \% pada putaran $2000 \mathrm{rpm}$ dan terjadi penurunan sebesar 2,94\% pada putaran $2000 \mathrm{rpm}$ dan pada putaran $3200 \mathrm{rpm}$ sampai $3900 \mathrm{rpm}$ torsi mengalami peningkatan sebesar $16.09 \%$, sebelum kembali turun pada putaran $4000 \mathrm{rpm}$ (DIMAS, 2019).

2. Percobaan Kedua Performa Mesin untuk Data Mesin Disel dengan Turbocharger

Berikut merupakan data karakteristik turbocharger yang digunakan saat melakukan uji coba dengan menggunakan mesin diesel DAIHATSU tipe CB-23. (Eko, 2019).

Tabel 3

Data Hasil Pengujian Daya dengan Turbocharger dan Turbocharger (Sony Uji Permana.,2020)

\begin{tabular}{ccc}
\hline Rpm & aya Dengan Turbocharger & Daya Tanpa Turbocharger \\
\hline 1200 & $8 \mathrm{HP}$ & $5 \mathrm{HP}$ \\
\hline 1400 & $11 \mathrm{HP}$ & $8 \mathrm{HP}$ \\
\hline 1600 & $13 \mathrm{HP}$ & $10 \mathrm{HP}$ \\
\hline 1800 & $15 \mathrm{HP}$ & $12 \mathrm{HP}$ \\
\hline 2000 & $17 \mathrm{HP}$ & $14 \mathrm{HP}$ \\
\hline 2200 & $20 \mathrm{HP}$ & $16 \mathrm{HP}$ \\
\hline 2400 & $23 \mathrm{HP}$ & $17 \mathrm{HP}$ \\
\hline 2600 & $24 \mathrm{HP}$ & $19 \mathrm{HP}$ \\
\hline 2800 & $25 \mathrm{HP}$ & $20 \mathrm{HP}$ \\
\hline 3000 & $26 \mathrm{HP}$ & $20 \mathrm{HP}$ \\
\hline 3200 & $27 \mathrm{HP}$ & $20 \mathrm{HP}$ \\
\hline
\end{tabular}




\begin{tabular}{ccc}
\hline Rpm & aya Dengan Turbocharger & Daya Tanpa Turbocharger \\
\hline 3400 & $28.33 \mathrm{HP}$ & $20.49 \mathrm{HP}$ \\
\hline 3600 & $26 \mathrm{HP}$ & $20.99 \mathrm{HP}$ \\
\hline 3800 & $25 \mathrm{HP}$ & $20 \mathrm{HP}$ \\
\hline 4000 & $24 \mathrm{HP}$ & $19 \mathrm{HP}$ \\
\hline
\end{tabular}

Pada table 3 dapat dilihat perbandingan daya mesin dengan turbocharger dan tanpa turbocharger pada rpm berbeda yang diuji oleh Philip Kristanto, Willyanto (Arviyanto, 2019) melakukan penelitian pada motor DAIHATSU tipe CB-23 yang menggunkan turbocharger dan tidak menggunkan turbocharger. Pada penelitian tersebut dapat diamati mesin dengan turbocharger memiliki daya sebesar 28,33 HP pada putaran $3400 \mathrm{rpm}$ dan mesin tanpa turbocharger memiliki daya sebesar 20,99 pada putaran $3600 \mathrm{rpm}$. Mesin dengan turbocharger memiliki daya maksimum sebesar 24 HP pada putaran $4000 \mathrm{rpm}$ sedangkan pada mesin tanpa menggunakan turbocharger memiliki daya maksimum sebesar 19 HP pada putaran $4000 \mathrm{rpm}$, sehingga dapat dikatakan mesin dengan turbocharger memiliki daya yang lebih besar dibandingkan tanpa menggunkan turbocharger (Sulaksono, 2012).

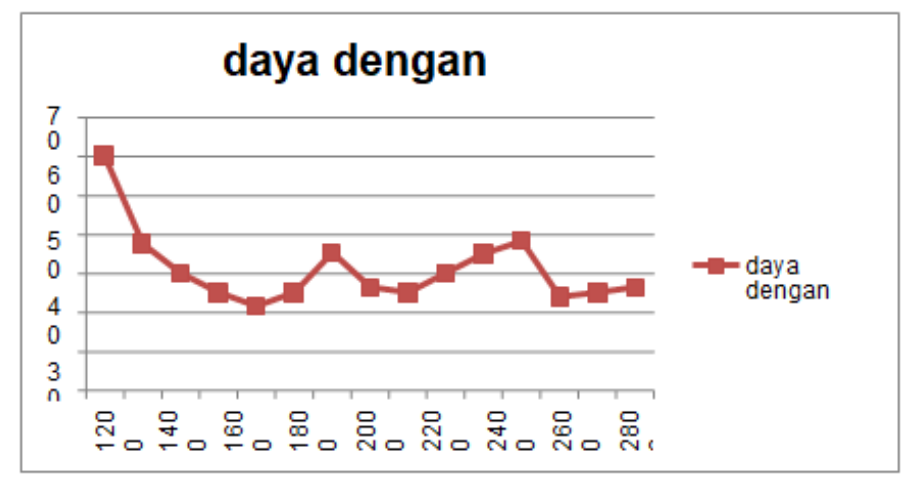

Grafik 3

Data Daya dari Percobaan 2

Pada grafik 3 delta daya dari percobaan dua mesin yang menggunkan turbocharger pada putaran awal $1200 \mathrm{rpm}$ memiliki daya sebesar $60 \%$ dan pada putaran $1400 \mathrm{rpm}$ sampai dengan putaran $2000 \mathrm{rpm}$ terjadi penurunan daya sebesar 21,43\% dan pada putaran $2400 \mathrm{rpm}$ daya kembali naik sebesar 35,29\% sampai dengan 38,26\% pada putaran 3400 rpm sebelum kembali turun pada putaran 3600 rpm. 


\section{Tabel 4}

Data Hasil Pengujian Torsi dengan Turbocharger dan Tanpa Turbocharger (Eko, 2019)

\begin{tabular}{ccc}
\hline Rpm & $\begin{array}{c}\text { torsi dengan } \\
\text { turbocharger }\end{array}$ & $\begin{array}{c}\text { Torsi tanpa } \\
\text { turbocharger }\end{array}$ \\
\hline 1200 & $50 \mathrm{Nm}$ & $43 \mathrm{Nm}$ \\
\hline 1400 & $53 \mathrm{Nm}$ & $45 \mathrm{Nm}$ \\
\hline 1600 & $55 \mathrm{Nm}$ & $47 \mathrm{Nm}$ \\
\hline 1800 & $58 \mathrm{Nm}$ & $48 \mathrm{Nm}$ \\
\hline 2000 & $63 \mathrm{Nm}$ & $50 \mathrm{Nm}$ \\
\hline 2200 & $64 \mathrm{Nm}$ & $52 \mathrm{Nm}$ \\
\hline 2400 & $65.89 \mathrm{Nm}$ & $53.79 \mathrm{Nm}$ \\
\hline 2600 & $64 \mathrm{Nm}$ & $52.5 \mathrm{Nm}$ \\
\hline 2800 & $63 \mathrm{Nm}$ & $52 \mathrm{Nm}$ \\
\hline 3000 & $62 \mathrm{Nm}$ & $45 \mathrm{Nm}$ \\
\hline 3200 & $60 \mathrm{Nm}$ & $44 \mathrm{Nm}$ \\
\hline 3400 & $57 \mathrm{Nm}$ & $43 \mathrm{Nm}$ \\
\hline 3600 & $55 \mathrm{Nm}$ & $42 \mathrm{Nm}$ \\
\hline 3800 & $50 \mathrm{Nm}$ & $40 \mathrm{Nm}$ \\
\hline 4000 & $47 \mathrm{Nm}$ & $35 \mathrm{Nm}$ \\
\hline
\end{tabular}

Pada table 4 Philip Kristanto, Willyanto (Arviyanto, 2019) melakukan penelitian pada mesin Daihatsu tipe CB-23, dari table diatas dapat diamati perbandingan torsi mesin diesel yang menggunakan turbocharger dan mesin diesel tanpa menggunakan turbocharger, pada mesin diesel yang menggunakan turbocharger memiliki torsi sebesar $65,89 \mathrm{Nm}$ pada putaran $2400 \mathrm{rpm}$ sedangkan mesin tanpa turbocharger mempunyai torsi paling tinggi pada putaran $2400 \mathrm{rpm}$ dengan torsi $53,79 \mathrm{Nm}$.

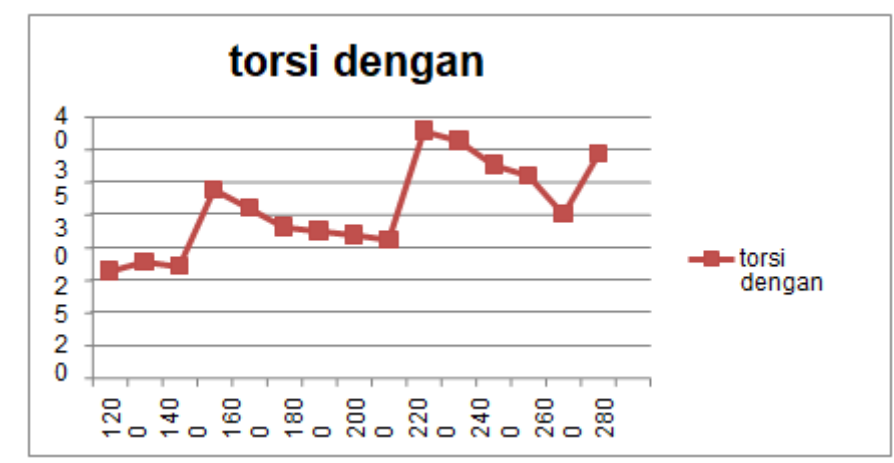

\section{Grafik 4}

\section{Delta Torsi dari Percobaan 2}

Pada grafik 4 delta torsi dari percobaan 2 pada putaran awal yaitu $1200 \mathrm{rpm}$ mempunyai torsi sebesar 16,28 \% dan terus mengalami kenaikan sebesar 28,83\% pada putaran $1800 \mathrm{rpm}$ sampai dengan $37,78 \%$ pada putaran $3000 \mathrm{rpm}$ sebelum mengalami penurunan sebesar $35 \%$ pada putaran $3800 \mathrm{rpm}$. Mesin diesel dengan 
turbocharger memiliki delta torsi maksimum sebesar 34,29\% pada putaran $4000 \mathrm{rpm}$ (Nurpratama, 2017).

3. Percobaan Ketiga Performa Mesin untuk Data Mesin Diesel Turbocharger dengan Intercooler

yang digunakan saat melakukan uji coba dengan menggunakan mesin diesel turbocharger degan intercooler (Biyantoro \& Muhadi., 2010).

Tabel 5

Data Hasil Pengujian Daya Dengan Turbocharger dan Tanpa Turbocharger

(Biyantoro \& Muhadi., 2010)

\begin{tabular}{ccc}
\hline Rpm & $\begin{array}{c}\text { Daya dengan } \\
\text { turbocharger }\end{array}$ & $\begin{array}{c}\text { Daya tanpa } \\
\text { turbocharger }\end{array}$ \\
\hline 1300 & $59 \mathrm{Hp}$ & - \\
\hline 1500 & $70 \mathrm{Hp}$ & - \\
\hline 1700 & $83 \mathrm{Hp}$ & $43 \mathrm{Hp}$ \\
\hline 1900 & $100 \mathrm{Hp}$ & $58 \mathrm{Hp}$ \\
\hline 2100 & $117 \mathrm{Hp}$ & $70 \mathrm{Hp}$ \\
\hline 2300 & $128 \mathrm{Hp}$ & $76 \mathrm{Hp}$ \\
\hline 2500 & $130 \mathrm{Hp}$ & $79 \mathrm{Hp}$ \\
\hline 2700 & $128 \mathrm{Hp}$ & $78 \mathrm{Hp}$ \\
\hline 2900 & $125 \mathrm{Hp}$ & $76 \mathrm{Hp}$ \\
\hline 3100 & $110 \mathrm{Hp}$ & - \\
\hline 3300 & $100 \mathrm{Hp}$ & - \\
\hline
\end{tabular}

Pada table 5 Mahadi (Biyantoro \& Muhadi, 2010) melakukan penelitian mesin diesel turbocharger dengan intercooler dan mesin diesel tanpa turbocharger dan intercooler dari table diatas dapat diamati mesin diesel turbocharger dengan intercooler dimulai dari putaran $1300 \mathrm{rpm}$ dengan daya sebesar $59 \mathrm{Hp}$ sampai dengan $3300 \mathrm{rpm}$ dan memiliki daya $100 \mathrm{Hp}$, sedangkan mesin tanpa turbocharger dan tanpa intercooler putaran awal dimulai pada putaran $1700 \mathrm{rpm}$ dengan daya sebesar $43 \mathrm{Hp}$ sampai putaran $2900 \mathrm{rpm}$ dengan daya sebesar $76 \mathrm{Hp}$. Mesin diesel turbocharger mempunyai daya paling besar yaitu $130 \mathrm{Hp}$ pada putaran $2500 \mathrm{rpm}$ sedangkan mesin tanpa turbocharger dan intercooler memiliki daya paling besar yaitu sebesar $79 \mathrm{Hp}$ pada putaran $2500 \mathrm{rpm}$ (Kusnadi, 2015).

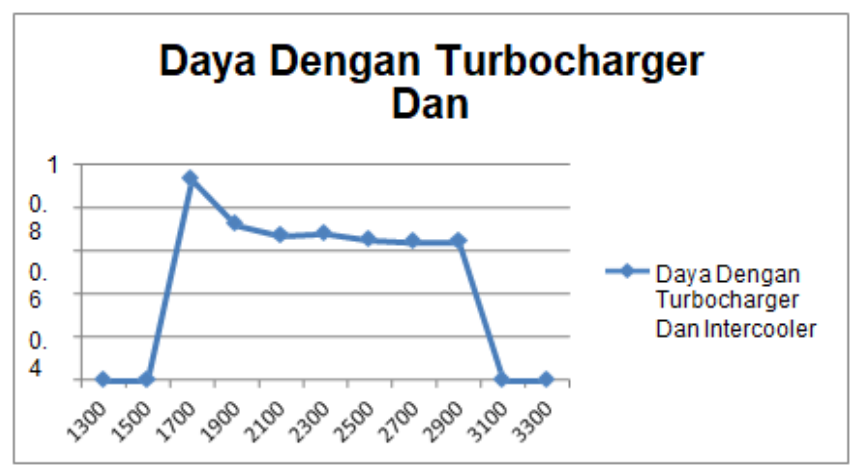

Grafik 5

Delta Daya dari Percobaan 3 
Pada grafik 5 delta daya dari percobaan 3 penelitian yang dilakukan oleh Mahadi (Biyantoro \& Muhadi, 2010) mesin diesel turbocharger dengan intercooler pada putaran $1700 \mathrm{rpm}$ terjadi peningkatan daya sebesar 0,93\%, sedangkan pada $1900 \mathrm{rpm}$ daya kembali berubah sebesar $0,72 \%$. Daya maksimum yang dihasil kan oleh mesin diesel turbocharger dengan intercooler sebesar 0,64\% pada putaran 2900 rpm (Rohman, 2018).

\section{Tabel 6}

Data Hasil Pengujian Torsi dengan Turbocharger dan Tanpa Turbocharger (Biyantoro \& Muhadi, 2010)

\begin{tabular}{ccc}
\hline Rpm & $\begin{array}{c}\text { Torsi dengan } \\
\text { turbocharger }\end{array}$ & $\begin{array}{c}\text { torsi tanpa } \\
\text { turbocharger }\end{array}$ \\
\hline 1300 & $32 \mathrm{Kg}-\mathrm{m}$ & - \\
\hline 1500 & $34 \mathrm{Kg}-\mathrm{m}$ & - \\
\hline 1700 & $36 \mathrm{Kg}-\mathrm{m}$ & $19 \mathrm{Kg}-\mathrm{m}$ \\
\hline 1900 & $38 \mathrm{Kg}-\mathrm{m}$ & $22 \mathrm{Kg}-\mathrm{m}$ \\
\hline 2100 & $39 \mathrm{Kg}-\mathrm{m}$ & $24 \mathrm{Kg}-\mathrm{m}$ \\
\hline 2300 & $40 \mathrm{Kg}-\mathrm{m}$ & $23 \mathrm{Kg}-\mathrm{m}$ \\
\hline 2500 & $37 \mathrm{Kg}-\mathrm{m}$ & $22 \mathrm{Kg}-\mathrm{m}$ \\
\hline 2700 & $32 \mathrm{Kg}-\mathrm{m}$ & $20 \mathrm{Kg}-\mathrm{m}$ \\
\hline 2900 & $31 \mathrm{Kg}-\mathrm{m}$ & $19 \mathrm{Kg}-\mathrm{m}$ \\
\hline 3100 & $26 \mathrm{Kg}-\mathrm{m}$ & - \\
\hline 3300 & $22 \mathrm{Kg}-\mathrm{m}$ & - \\
\hline
\end{tabular}

Pada table 6 Mahadi (Wibowo, 2019) melakukan penelitian pada mesin diesel turbocharger dengan intercooler. Dari table dapat dilihat bahwa mesin diesel turbocharger dengan intercooler mempunyai torsi paling besar pada putaran 2300 rpm dengan besar torsi $40 \mathrm{Kg}-\mathrm{m}$, dari rpm awal 1300 dengan besar torsi $32 \mathrm{Kg}-\mathrm{m}$ sedangkan mesin diesel tanpa turbocharger dan intercooler torsi paling besar pada putaran $2100 \mathrm{rpm}$ dengan torsi $24 \mathrm{Kg}-\mathrm{m}$ dengan putaran awal torsi pada $1700 \mathrm{rpm}$ sebesar $19 \mathrm{Kg}-\mathrm{m}$. Daya maksimum torsi mesin diesel turbocharger dengan intercooler adalah $22 \mathrm{Kg}$-m pada rpm 3300 dan untuk torsi maksimum mesin diesel tanpa turbocharger dan intercooler sebesar $19 \mathrm{Kg}-\mathrm{m}$ pada putaran $2900 \mathrm{rpm}$.

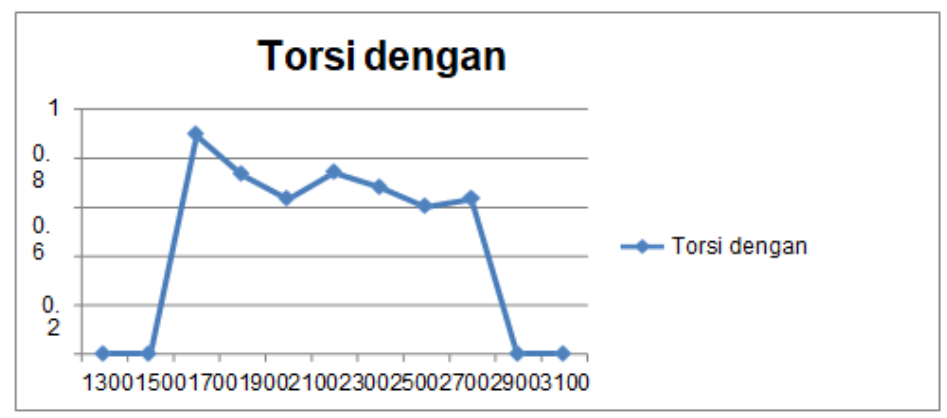

Grafik 6

Delta Torsi dari Percobaan 3 
Pada grafik 6 delta torsi percobaan 3 terjadi peningkatan torsi pada putaran $1700 \mathrm{rpm}$ sebesar $0,89 \%$ dan pada putaran 2700 terjadi penurunan torsi sebesar 0,63 $\%$ dan torsi kembali meningkat pada putaran $2300 \mathrm{rpm}$ sebesar 0,74\%, pada percobaan tiga grafik delta torsi memiliki torsi maksimum pada sebesar $0,69 \%$ terdapat pada putaran $2900 \mathrm{rpm}$.

\section{Kesimpulan}

Secara umum turbocharger pada mesin diesel mobil yang diuji dengan dynamometer dapat menaikan unjuk kerja mesin diesel yaitu kenaikan daya maksimum sebesar 57,24 kW pada putaran $3500 \mathrm{rpm}$ sedangkan mesin tanpa turbocharger daya maksimum yang dihasilkan sebesar $52,15 \mathrm{kw}$. Untuk masksimum torsi dengan turbocharger sebesar 18,32 N.m pada putaran $200 \mathrm{rpm}$ dan tanpa turbocharger torsi maksimum yang dihasilkan sebesar 16,52 N.m pada putaran 1800 rpm. Terjadi peningkatan nilai daya maksimum pada mesin dengan menggunakan turbocharger sebanyak 9,76\% dari kondisi mesin tanpa turbocharger dan peningkatan nilai torsi maksimum pada mesin dengan menggunakan turbocharger sebanyak 10,84\% dari kondisi mesin tanpa turbocharger.

Pada data kedua mesin diesel Daihatsi tipe CB-23 yang menggunakan turbocharger mempunyai daya maksimum sebesar 28,33 HP yang terjadi pada putaran 3400 rpm sedangkan mesin diesel tanpa menggunakan turbocharger memiliki daya maksimum sebesar 20,99 HP pada putaran $3600 \mathrm{rpm}$. Untuk maksimum torsi yang dihasilkan mesin dengan turbocharger sebesar 65,89 N.m pada putaran $2400 \mathrm{rpm}$ dan torsi maksimum untuk mesin diesel tanpa turbocharger sebesar 53,79 N.m pada putaran $2400 \mathrm{rpm}$. Mesin dengan turbocharger akan meningkatkan daya dari motor sebesar $34,97 \%$ dan nilai torsi mesin yang dihasilkan menggunakan turbocharger lebih tinggi dibandingkan dengan mesin normal.

Untuk data pada percobaan ketiga daya yang dihasilkan pada mesin diesel ketika menggunakan turbocharger dengan intercooler mempunyai daya maksimum sebesar $130 \mathrm{Hp}$ pada putaran $2500 \mathrm{rpm}$ sedangkan mesin tanpa turbocharger dan intercooler memiliki daya paling besar yaitu sebesar $79 \mathrm{Hp}$ pada putaran $2500 \mathrm{rpm}$ dengan putaran awal mesin yang berbeda. 


\section{BIBLIOGRAFI}

Arviyanto, N. (2019). Analisis Shaft Turbocharger Mesin Diesel Generator Yang Patah Di Mv. Dk 02. Politeknik Ilmu Pelayaran Semarang.

Biyantoro, D., \& Muhadi, A. W. (2010). Kajian Pemisahan Zr-Hf Dengan Proses Ekstraksi Cair-Cair. Prosiding Pertemuan Dan Presentasi Ilmiah Penelitian Dasar Ilmu Pengetahuan Dan Teknologi Nuklir. Yogyakarta.

Dimas, T. K. (2019). Pengaruh Kualitas Udara Dan Kualitas Perawatan Terhadap Kinerja Turbocharger Dan Strategi Kinerja Turbocharger Di Mv. Sri Wandari Indah. Politeknik Ilmu Pelayaran Semarang.

Eko, B. (2019). Identifikasi Menurunnya Kerja Turbocharger Pada Mesin Diesel Generator Di Mv. Nur Allya Dengan Metode Shel Dan Usg. Politeknik Ilmu Pelayaran Semarang.

Ginting, A. S., \& Hazwi, M. (2014). Analisa Performansi Pada Mobil Toyota Fortuner Mesin Diesel Tipe 2kd-Ftv Vn Turbo Intercooler. E-Dinamis, 10(2).

Hendrawan, A., Laras, T., Sucahyowati, H., \& Cahyandi, K. (2020). Peningkatan Kepemimpinan Transformasional Dengan Organizational Citizenship Behavior (Ocb). Proceeding Of The Urecol, 78-89.

Kusnadi, K. (2015). Pengaruh Penggunaan Turbocharger Terhadap Unjuk Kerja Mesin Diesel Tipe L 300. Nozzle: Journal Mechanical Engineering, 3(1).

Mahfudiyanto, H., Rijanto, A., \& Zulfika, D. N. (2020). Pengaruh Turbocharger Terhadap Tekanan Efektif Rata-Rata Dan Batas Asap Pada Mitsubishi Canter Fe73 110 Ps. Majamecha, 2(2), 134-140.

Nasution, A., \& Ibrahim, H. (2017). Kajian Studi Turbocharger Terhadap Performasi Motor Bakar Diesel Daya 150 Ps.

Nurpratama, R. (2017). Analisa Penyebab Kerusakan Turbocharger Mesin Diesel Mwm Tbd 234 V8 Menggunakan Metode Fault Tree Analysis. Politeknik Perkapalan Negeri Surabaya.

Purwanto, H. (2005). Pengaruh Turbocharger Terhadap Daya Pada Motor Diesel. Majalah Ilmiah Momentum, 1(1).

Rohman, S. (2018). Identifikasi Kurangnya Perawatan Turbocharger Pada Mesin Diesel Generator Di Mv. Isa Express Dengan Metode Fishbone Dan Fta. Politeknik Ilmu Pelayaran Semarang.

Sulaksono, B. (2012). Evaluasi Unjuk Kerja Sistem Turbocharger Pada Mesin Diesel. Mekanikal: Jurnal Ilmiah Teknik Mesin, 8(2), 128-132. 
Sumardiyanto, D., \& Susilowati, S. E. (2017). Pengaruh Kondisi Udara Bilas Terhadap Kinerja Mesin Diesel. Jurnal Konversi Energi Dan Manufaktur Unj, 4(2), 81-88.

Wibowo, A. (2019). Analisis Penggunaan Turbo Cyclone Pada Mesin Diesel L300 Terhadap Kinerja Fuel Consumption Dengan Menggunakan Alat Uji Prestasi Mesin. Universitas Mercu Buana Jakarta.

Yusuf, Y., Caturwati, N. K., Rosyadi, I., Haryadi, H., \& Abdullah, S. (2019). Analisis Prestasi Mesin Mobil Diesel Turbocharger Yang Diuji Dengan Dynamometer. Teknika: Jurnal Sains Dan Teknologi, 15(2), 92-101. 